\title{
Glottic Infection by Herpes Simplex Virus in an Irradiated Patient
}

\author{
Hyung Gu Kim ${ }^{1}$, Sang Yeon Lee ${ }^{1}$, Doh Young Lee ${ }^{1}$, and Young Ho Jung ${ }^{2}$ \\ ${ }^{I}$ Department of Otolaryngology-Head and Neck Surgery, Seoul National University Hospital, \\ Seoul National University College of Medicine, Seoul; and ${ }^{2}$ Department of Otorhinolaryngology-Head and Neck Surgery, \\ Boramae Medical Center, Seoul National University College of Medicine, Seoul, Korea
}

\author{
방사선 치료를 받은 성문암 환자에서 발생한 후두의 단순헤르페스 바이러스 감염 \\ 김형규 $^{1} \cdot$ 이상연 ${ }^{1} \cdot$ 이도영 $\cdot$ 정영호 ${ }^{2}$ \\ 서울대학교 의과대학 서울대학교병원 이비인후과학교실, ${ }^{1}$ 서울대학교 의과대학 보라매병원 이비인후과학교실 ${ }^{2}$
}

\author{
Received May 13, 2014 \\ Revised September 12, 2014 \\ Accepted September 28, 2014 \\ Address for correspondence \\ Young Ho Jung, MD, PhD \\ Department of Otorhinolaryngology- \\ Head and Neck Surgery, Boramae \\ Medical Center, Seoul National \\ University College of Medicine, \\ 20 Boramae-ro 5-gil, Dongjak-gu, \\ Seoul 156-707, Korea \\ Tel +82-2-870-2445 \\ Fax $+82-2-831-2826$ \\ E-mail entist@naver.com
}

Herpetic laryngitis is extremely rare in healthy adults. The local factors that increase susceptibility to herpes simplex virus include irradiation on the head and neck area. A 66-year-old man who had history of supraglottic cancer had voice change 4 years after the radiotherapy. On laryngscopic examination, the erosive mucosal lesion was found on his left vocal fold. A pathologic examination of the lesion by suspension laryngoscopy revealed that the lesion was herpetic laryngitis, which was confirmed by immunohistochemical stain as herpes simplex virus. Herpetic laryngitis should be in the index of differential diagnosis in patients with laryngitis who have the history of irradiation on the neck.

Korean J Otorhinolaryngol-Head Neck Surg 2015;58(3):217-9

Key Words Glottic cancer· Herpes simplex virus · Laryngitis · Radiotherapy.
Introduction

Herpetic laryngitis is a rare inflammatory disease caused by either the Herpes simplex virus (HSV) or the varicella zoster virus (VZV). It can be usually found in pediatric patients or immune-compromised adults, but can occur in both immune-competent and immune-compromised individuals. ${ }^{1,2)}$ The laryngeal manifestations of herpetic infection are variable. Thus, laryngeal endoscopy cannot definitively distinguish the condition from others in the differential diagnosis, such as extensive laryngeal neoplasm, laryngeal tuberculosis, fungal infection, syphilis, abscess, and nonspecific laryngeal inflammation. ${ }^{3,4)}$ We report herein a case of herpetic laryngitis in an adult patient who had supraglottic cancer and cured by radiation therapy.

\section{Case}

A 66-year-old man presented to the otolaryngology clinic with voice change. On laryngoscopic examination, an erosive mucosal lesion was found on the left vocal folds, resembling acute laryngitis rather than malignancy (Fig. 1B). Four years ago, he was diagnosed supraglottic cancer at the right side of tip of epiglottis (differentiated squamous cell carcinoma, T1N0M0). The tumor was resected by laryngeal microsurgery and addional radiotherapy of 60 Gy for 2 months was necessary for inaccurate and irregular resection margin. He was then followed at either 3- or 6-month intervals with laryngoscopic examination. During the follow-up period, his only complaints were dry mouth, which was considered to be radiation-associated mucositis, and mild dysphagia that improved with rehabilitation therapy. There was no residual 

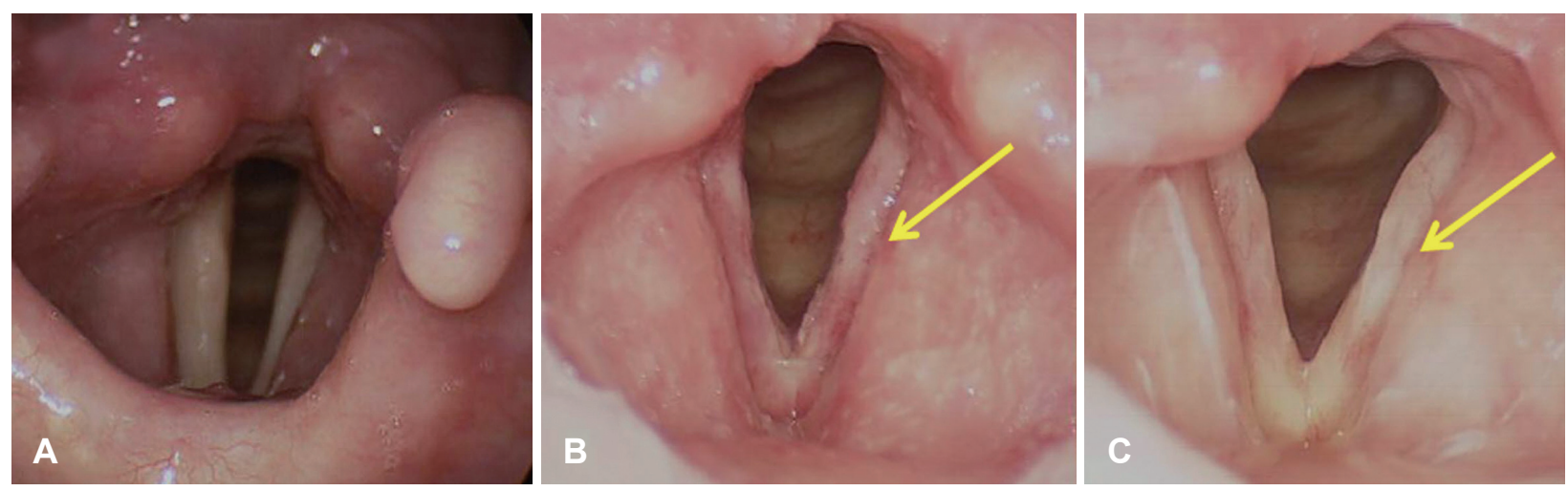

Fig. 1. No residual lesion or evidence of recurrence of supraglottic cancer 6 months after radiation therapy (A), ulcerative lesion on left vocal folds (arrow) (B), complete recovery 2 month after diagnostic laryngeal microsurgery (arrow) (C).

Fig. 2. Affected squamous epithelial cells show enlarged nuclei with nuclear eccentuation, eosinophilic nuclear inclusion and occasional multinucleated giant cells (hematoxylin eosin, $\times 400)(A)$, strong positive reaction to $\mathrm{HSV}$ is demonstrated by immunohistochemical stain $($ HSV $\times 400)(B)$. HSV: Herpes simplex virus.
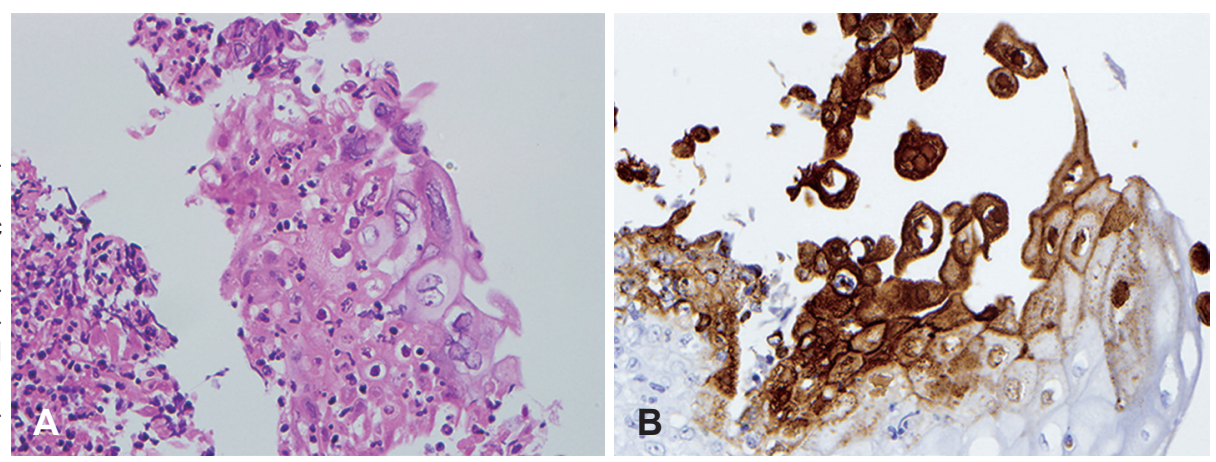

lesion detected, and no evidence of recurrence (Fig. 1A). He was a heavy drinker and had mild liver cirrhosis with the liver function of Child-Pugh classification A. He also had longstanding stable chronic kidney disease, with a glomerular filtration rate of $37.5 \mathrm{~mL} / \mathrm{min} / 1.73 \mathrm{~m}^{2}$.

Forty-five months after the postoperative radiation therapy, he had his voice change and came to our outpatient department. On physical examination, we found the lesion as described above.

After 2 weeks of medical treatment for his left vocal fold lesion with methylprednisolone, a proton pump inhibitor, and antacids, his voice partially improved but there was no change in the extent of the lesion. So, we decided to perform a larynx CT scan and whole-body PET-CT, but there was no abnormally enhancing lesion and no suspicious findings to suggest malignancy recurrence. Although these studies were reassuring, we were concerned that the lesion did not respond to medical treatment and decided to perform laryngeal microsurgery to obtain a histologic diagnosis. The lesion did not change for a one month from the first detection, the larynx was re-examined under general anesthesia on the day of surgery, and multiple biopsies and frozen sections were sent to pathology. All specimens were negative for malignancy, demonstrating an atypical squamous epithelium with an ulcerated base that suggested virus-related change. Approximately 1 week later, the final surgical pathology was available, where the histopathologic examination revealed diffuse ulceration of laryngeal mucosa accompanied by neutrophils and some lymphocytes (Fig. 2A). The squamous epithelial cells show nuclear and cytoplamic enlargement with focal multinucleated giant cell formation. Margination of nuclear chromatin and Cowdry type A inclusion bodies are characteristic of HSV infected cells. Additionally, HSV infection was confirmed by immunohistochemistry using anti-HSV antibody (Dako, Carpinteria, CA, USA) (Fig. 2B). Serologic examination to detect HSV antibodies was positive for IgG and negative for IgM. Because the disease was regarded as self-limiting, an antiviral agent was not prescribed. After 2 months, the inflammation on his vocal fold subsided; he remained disease-free after 12 months of follow-up (Fig. 1C).

\section{Discussion}

Herpetic laryngitis is extremely rare, accounting for only one percent of laryngitis cases. ${ }^{5)}$ Both possible pathogens, HSV and VZV, are members of the Herpes viridae family, 
characterized by the ability to establish lifetime latencies inside specific cells, with a particular preference for the sensory ganglia of the dorsal root. ${ }^{6,11,12)}$ Various signs of herpetic laryngitis have been described, including vesicles, ulcers, bulky fibrinous lesions of the endolarynx, even vocal cord paralysis. ${ }^{7)}$ Ulcerative lesions may involve either the supraglottis or glottis, whereas edema is most commonly described in the subglottic region. ${ }^{2)}$

Confirmation of herpes virus infection is achieved by culturing the virus from laryngeal tissue but the sensitivity of this method is limited. Multiple intranuclear inclusions in histologic sections and immunohistochemical staining for herpesvirus agent are also evidence of herpes virus infection. ${ }^{2,6)}$ In reported cases, we found these characteristic histologic feature and immunohistochemical staining using anti-HSV antibody was also positive.

The herpetic laryngitis can occur in all age bracket. It can involve children, presenting with clinically significant inflammatory conditions such as croup, ${ }^{8-10)}$ Mancao et al. ${ }^{8)}$ reported cases of herpetic croup in pediatric patients. The patients in immune-compromised conditions such as acquired immunodeficiency syndrome or long-term corticosteroid use are more vulnerable to viral infection. However, there are also reported cases of herpetic infection in immune-competent patients and some of the reports describing immunecompetent adult patients involve possible locoregional factors, such as irradiation, that could worsen local immunity. Our patient had a history of radiation treatment and complained of dry mouth and throat, factors that could have increased his susceptibility to HSV invasion.

As described above, laryngeal disorders provoked by the herpes virus are characterized by the large spectrum of presentations and polymorphism, and can simulate mucous lesions such as extensive laryngeal neoplasm, laryngeal tuberculosis, fungal infection, syphilis, abscess or nonspecific laryngeal inflammation. Especially in patient who had a history of malignancy like our case, it is difficult to distinguish benign ulcerative lesions from recurrence of malignancy. There- fore when following up patients with a history of laryngeal cancer, ulceration of the larynx should raise suspicion for malignancy recurrence and pathologic evaluation including biopsy under general anesthesia if necessary, should be conducted to confirm the diagnosis.

Herpetic laryngitis should be included in the differential diagnosis when patients have complaints localized to the larynx, especially in the situation of an immune-compromised status. In a patient with bad local immunity in throat due to radiation therapy or dry mucosa ulcerative lesions of the vocal fold could be caused by the infection of the herpes virus.

\section{Acknowledgments}

This article is presented at IFOS 2013 Seoul, Korea.

\section{REFERENCES}

1) Ferrandis Perepérez E, Artazkoz del Toro JJ, Serrano Badía E. [Herpetic laryngeal involvement simulating neoplasm]. Acta Otorrinolaringol Esp 1997;48(1):69-71.

2) Vrabec JT, Molina CP, West B. Herpes simplex viral laryngitis. Ann Otol Rhinol Laryngol 2000;109(6):611-4

3) Karnauchow PN, Kaul WH. Chronic herpetic laryngitis with oropharyngitis. Ann Otol Rhinol Laryngol 1988;97(3 Pt 1):286-8.

4) Zhang S, Farmer TL, Frable MA, Powers CN. Adult herpetic laryngitis with concurrent candidal infection: a case report and literature review. Arch Otolaryngol Head Neck Surg 2000;126(5):672-4.

5) Mesolella M, Testa B, Mesolella C, Giuliano A, Testa G. [Herpes of the larynx. Apropos of 3 cases]. Ann Otolaryngol Chir Cervicofac 1993;110(6):337-40.

6) Pinto JA, Pinto HC, Ramalho Jda R. Laryngeal herpes: a case report. J Voice 2002;16(4):560-3.

7) Magnussen CR, Patanella HP. Herpes simplex virus and recurrent laryngeal nerve paralysis. Report of a case and review of the literature. Arch Intern Med 1979;139(12):1423-4.

8) Mancao MY, Sindel LJ, Richardson PH, Silver FM. Herpetic croup: two case reports and a review of the literature. Acta Paediatr 1996; 85(1):118-20.

9) Bogger-Goren S. Acute epiglottitis caused by herpes simplex virus. Pediatr Infect Dis J 1987;6(12):1133-4.

10) Harris JB, Lusk R, Wagener JS, Andersen RD. Acute viral laryngotracheitis complicated by herpes simplex virus infection. Otolaryngol Head Neck Surg 1987;96(2):190-3.

11) Park BS, Park HS, Lee HJ, Koo SK. A case of herpes zoster laryngitis with isolated vagus nerve paralysis. Korean J OtorhinolaryngolHead Neck Surg 2010;53(10):636-9.

12) Lee SH, Lee JK, Kwon HJ, Jin SM. Herpes Zoster Oticus with multiple cranial nerve involvement: 2 cases. Korean J Otorhinolaryngol-Head Neck Surg 2007;50(7):635-8. 